\title{
Estudio morfométrico de los epidídimos durante el desarrollo postnatal de corderos Barbados Blackbelly
}

\section{Morphometric study of the epididymes during the postnatal development in Barbados Blackbelly ram lambs}

\author{
Anahy Danae Vargas-Velázqueza, Héctor Jiménez-Severianob
}

\begin{abstract}
RESUMEN
Para caracterizar el desarrollo de los epidídimos, se castraron corderos Blackbelly al nacimiento y cada tres semanas hasta la 21 ( $n=4$ a 6 por grupo). Se registró el peso de los epidídimos y de las tres regiones anatómicas y se tomaron muestras para morfometría. Se calculó el porcentaje de tejido tubular, el diámetro tubular, el grosor y área de la capa muscular, la altura y área del epitelio, y el diámetro y área de la luz tubular. El mayor crecimiento del epidídimo se observó entre las semanas 9 y 18; la cola comenzó a desarrollarse antes que las otras regiones; el peso de ésta fue mayor entre el nacimiento y la semana 12, pero de la semana 15 a la 21 no difirió de la cabeza. En general, el diámetro tubular, el grosor y área de la capa muscular y el diámetro y área de la luz fueron mayores en la cola. La altura del epitelio fue mayor en la cola hasta la semana 9, pero la situación se invirtió a partir de la semana 12 . De acuerdo a lo que se conoce de esta raza, la cola comenzó a desarrollarse antes de aparecer la luz de los túbulos seminíferos y del aumento de las concentraciones de testosterona, mientras que el desarrollo de la cabeza y el cuerpo coincidió con el aumento de la capacidad esteroidogénica y la secreción del fluido tubular. Tales hallazgos sugieren diferentes requerimientos de estimulación endocrina y lumicrina para el desarrollo normal de las diferentes regiones del epidídimo.
\end{abstract}

PALABRAS CLAVE: Epidídimo; Desarrollo sexual; Ovinos tropicales; Corderos Blackbelly.

\begin{abstract}
To characterize the development of the epididymides, Barbados Blackbelly ram lambs were castrated at birth and every three weeks until wk 21 ( $n=4$ to 6 per group). The individual epididymal weight was recorded; the three anatomical regions (caput, corpus and cauda) of the left epididymis were weighed, and samples taken for morphometric studies. The percentage of tubular tissue was calculated, as well as the tubular diameter, the width and area of the muscular layer, the height and area of the epithelium, and the diameter and area of the tubular lumen. Data were analyzed to determine differences among the anatomical regions and ages. The greatest growth of the whole organ was observed between 9 and 18 wk; the cauda started developing earlier than the other anatomical regions; the cauda was heaviest between birth and wk 12, but from 15 to 21 wk the caput and cauda weights were similar to each other. Overall, tubular diameter, width and area of the muscular layer, and luminal diameter and area were greatest in the cauda epididymidis. The epithelium height was greatest in the cauda until wk 9, but the situation reversed from wk 12 onwards. According to previous information for this breed, cauda started developing before the increase of circulating testosterone concentrations, and before the seminiferous tubule lumen appeared, whilst the caput and corpus development coincided temporally with the increase of testicular steroidogenic capacity and tubular fluid secretion. Such findings suggest differential requirements of endocrine and lumicrine stimulation for the normal development of the various anatomical regions of the epididymis.
\end{abstract}

KEYWORDS: Epididymis; Sexual development; Tropical sheep; Blackbelly lambs.

Recibido el 19 de marzo de 2015. Aceptado el 23 de abril de 2015.

a Licenciatura en Medicina Veterinaria y Zootecnia, Universidad Autónoma Metropolitana, Xochimilco, DF, México.

b Centro Nacional de Investigación Disciplinaria en Fisiología y Mejoramiento Animal, INIFAP, Ajuchitlán, Querétaro, México. jimenez.hector@inifap.gob.mx correspondencia al segundo autor. 


\section{INTRODUCCIÓN}

Barbados Blackbelly es una raza de ovinos de pelo (Ovis aries) desarrollada en latitudes tropicales y bien adaptada a esas condiciones climáticas. Las hembras son precoces y prolíicas, con una larga estación reproductiva(1,2). Los estudios sobre el desarrollo sexual y capacidad reproductiva de los machos Blackbelly son escasos, pese a que esta información es importante para la evaluación, selección y uso de sementales jóvenes. El desarrollo testicular es importante, ya que la capacidad reproductiva y la fertilidad de los sementales dependen principalmente de una adecuada función testicular; sin embargo, la producción espermática debe completarse con la maduración celular, la cual se realiza durante el transporte de los espermatozoides por los epidídimos(3); cualquier falla del desarrollo de los epidídimos o en su función puede conducir a problemas de fertilidad, como consecuencia de trastornos en la maduración, incluso con una producción espermática adecuada(4). La maduración espermática es adquirida progresiva y simultáneamente, conforme los espermatozoides recorren la cabeza y el cuerpo del epidídimo(5), mientras que la cola sirve principalmente como lugar de almacenamiento de los espermatozoides funcionalmente maduros, ya que proporciona el ambiente óptimo para mantener su viabilidad durante varios días $(4,5,6)$.

La importancia funcional de la regionalización anatómica del epidídimo ha sido reconocida(7), ya que las diversas regiones anatómicas tienen diferentes patrones de expresión génica y proteica, acordes con las diferentes funciones en la maduración y almacenamiento de los espermatozoides (7). Es de esperarse que estas diferencias funcionales en los adultos, también estén presentes en las características morfométricas de las regiones anatómicas en etapas inmaduras, lo que podría sugerir diferentes requerimientos y mecanismos estimulatorios durante su desarrollo. Información previa sugiere que existen tales diferencias $(8,9)$; sin embargo, en el primer estudio(8) la única variable evaluada

\section{INTRODUCTION}

Barbados Blackbelly is a hair breed of sheep (Ovis aries), developed in tropical latitudes and is well adapted to tropical conditions. Ewes are precocious and highly prolific, having a long breeding season $(1,2)$. Studies of sexual development and reproductive capacity of Blackbelly males are scarce, albeit the importance of this information for the evaluation, selection and usage of young sires. Testis development is important, as the reproductive capacity and fertility of sires depends primarily on a satisfactory testicular function; however, adequate sperm production must be completed with cell maturation, which is achieved during sperm transit through the epididymis(3); any failure during the epididymal development or function might lead to fertility problems, as consequence of maturation disorders, even with adequate sperm production(4). Sperm maturation is acquired progressively and simultaneously as the sperm travel through the caput and corpus epididymidis(5), whilst the cauda serves primarily as a storage site for functionally mature sperm, since it provides the optimal environment to maintain sperm viability for several days $(4,5,6)$.

The functional importance of the anatomical regionalization of the epididymis has been further recognized(7), as the several anatomical regions have different patterns of gene and protein expression, in agreement with the different functions relative to sperm maturation and storage. It is expected that the functional differences among the anatomical regions in the adult epididymis are also present in the morphometric characteristics during the development of the epididymal anatomical regions, which could suggest differential requirements and stimulatory mechanisms during their development. Previous information suggests that such differences exist $(8,9)$; however, in the first study the only variable studied was the epididymal epithelium, whilst in the last study, the authors used lambs at an age when important developmental changes 
fue el epitelio del epidídimo, mientras que en el segundo(9), los corderos utilizados eran de una edad tal, que muchos de los cambios importantes en el desarrollo gonadal seguramente ya habían ocurrido. Una descripción anatómica detallada sería útil para responder preguntas importantes, no resueltas en los estudios anteriores; por lo tanto, el presente es un estudio exploratorio, donde se utilizaron técnicas de morfometría cuantitativa para caracterizar el desarrollo de las regiones anatómicas del epidídimo, entre el nacimiento y las 21 semanas de edad, en corderos Barbados Blackbelly.

\section{MATERIAL Y METODOS}

Animales y diseño experimental

Todos los procedimientos experimentales se realizaron de acuerdo con "International Guiding Principles for Biomedical Research Involving Animals" (disponible en: http://www.cioms.ch/ images/stories/CIOMS/IGP2012.pdf). El estudio se realizó en el estado de Querétaro, México $\left(20^{\circ} 43^{\prime} \mathrm{N}, 100^{\circ} 15^{\prime} \mathrm{O}\right)$. Se utilizaron 43 corderos de la raza Barbados Blackbelly nacidos en verano (julio a septiembre). Los corderos se alojaron en corrales al aire libre; antes del destete, a los corderos se les ofreció una dieta que contenía $14 \%$ de proteína cruda (78 \% de sorgo, $20 \%$ de harina de canola y $2 \%$ de minerales); después del destete a los 75 días de edad, se alimentaron con heno de alfalfa y el concentrado ya descrito, el agua siempre estuvo ad libitum. Los corderos se asignaron a ocho grupos experimentales; los corderos de cada grupo se castraron quirúrgicamente bajo anestesia local, al nacer (antes de 3 días de edad), o bien cuando tenían 3, 6, 9, 12, 15, 18 o 21 semanas de edad ( $n=4$ a 6 por grupo); dentro de cada grupo la diferencia de edad nunca fue mayor a 3 días. Todas las castraciones se realizaron durante septiembre a diciembre.

\section{Recolección y procesamiento de los tejidos}

A ambos epidídimos se les retiró todo el tejido adyacente y se pesaron por separado. El epidídimo izquierdo se dividió en sus tres must have already occurred. A detailed anatomical description would be useful to answer important questions do not solved in the previous studies; therefore, the present is an exploratory study, where quantitative morphometric techniques were used to characterize the development of the several anatomical regions of the epididymides, between birth and 21 wk of age, in Barbados Blackbelly ram lambs.

\section{MATERIAL AND METHODS}

Animals and experimental design

All the experimental procedures were performed according to the "International Guiding Principles for Biomedical Research Involving Animals" (available at: http://www.cioms.ch/images/ stories/CIOMS/IGP2012.pdf). The study was conducted in the state of Queretaro, Mexico (200 43' N, $\left.100^{\circ} 15^{\prime} \mathrm{W}\right)$. Forty-three summerborn (July to September) Barbados Blackbelly ram lambs were used. Lambs were always housed in outdoor pens; before weaning, lambs were creep fed with a diet containing $14 \%$ crude protein (78 \% sorghum, $20 \%$ canola meal and $2 \%$ minerals); after weaning at $75 \mathrm{~d}$ of age, lambs were offered alfalfa hay and a concentrate as described above, water was always available ad libitum. Lambs were allotted into eight experimental groups, each group were surgically castrated under local anesthesia either, at birth (before $3 \mathrm{~d}$ of age), or when they were $3,6,9,12,15,18$ or $21 \mathrm{wk}$ of age $(n=4$ to 6 per group), within each group the difference in age was never greater than $3 \mathrm{~d}$. All castrations were performed during September to December.

\section{Tissue collection and processing}

Both epididymides were trimmed off extraneous tissue and weighed separately. The left epididymis was divided in its three anatomical regions, caput, corpus and cauda(5). Each region was weighed and the percentage accounted for each region to the whole organ weight was calculated, these percentages were then used to estimate the 
regiones anatómicas, cabeza, cuerpo y cola(5). Cada región se pesó y se calculó el porcentaje que representaba cada una respecto al peso total del órgano; estos porcentajes se utilizaron para estimar el peso conjunto de ambos lados para cada región. Se obtuvieron muestras del epidídimo izquierdo, de las zonas 2 (cabeza), 5 (cuerpo) y $8 / 9$ (cola), de acuerdo con Gatti et al(5), y fueron fijadas y procesadas para histología(10). Se tomaron tres a cuatro cortes $(5 \mu \mathrm{m})$ de cada muestra, se montaron en portaobjetos recubiertos con gelatina y se dejaron secar durante toda la noche a $37^{\circ} \mathrm{C}$; los cortes se tiñeron con hematoxilina-eosina y se almacenaron a temperatura ambiente hasta que se llevó a cabo el análisis.

Evaluación morfométrica de los cortes de epidídimo

De cada cordero se eligieron al azar uno o dos cortes de cada región del epidídimo para ser observados bajo un microscopio de campo claro (Axiostar Plus, Carl Zeiss, México DF); se obtuvieron imágenes digitales a 100x o 200x (dependiendo de la edad del cordero y la variable evaluada) con una cámara digital (Color View II, Soft Imaging System, Lakewood CO) acoplada al microscopio. Las imágenes fueron adquiridas y procesadas utilizando un software de análisis de imágenes (AnalySIS Opti Basic, Soft Imaging System). El porcentaje de parénquima epididimal compuesto por tejido tubular en cada región se determinó en las imágenes tomadas a 100x. Cada corte se dividió en cuadrantes, un campo de cada cuadrante se eligió al azar y se le colocó un cuadrado de dimensiones conocidas $(945.5 \times 945.5 \mu \mathrm{m}) ;$ a continuación, todos los tubos dentro del cuadrado se delimitaron y el software calculó el área tubular total en el interior del cuadrado, la cual se utilizó para obtener el porcentaje de tejido tubular. Para obtener las variables del componente tubular del tejido epididimal, se trazó el contorno de 10 cortes tubulares redondos en cada región epididimal de cada cordero, incluyendo y sin incluir la capa muscular; además, se trazó el contorno de la paired weight of each region. Samples were obtained from the left epididymis, from the zones 2 (caput), 5 (corpus) and 8/9 (cauda)(5), and were fixed and processed for histology (10). Three to four sections $(5 \mu \mathrm{m})$ were made from each sample, mounted onto gelatin-coated glass slides and dried overnight at $37{ }^{\circ} \mathrm{C}$. Sections were stained with hematoxylin-eosin and stored at room temperature until quantitative morphometric analysis was conducted.

\section{Morphometric evaluation of epididymal} sections

One or two sections from each epididymal region and ram were randomly chosen and observed under a bright field microscope (Axiostar Plus, Carl Zeiss, Mexico DF); digital images were obtained at $100 x$ or 200x magnifications (depending on the age of the lamb and the variable to be recorded) with a digital camera (Color View II, Soft Imaging System, Lakewood $\mathrm{CO})$ attached to the microscope. Image acquiring and processing were performed using image analysis software (AnalySIS Opti Basic, Soft Imaging System). The percentage of the epididymal parenchyma composed of tubular tissue in each region was determined in images taken at a magnification of 100x. Each section was divided in quadrants, a field from each quadrant was randomly chosen and a square $(945.5 \times 945.5 \mu \mathrm{m})$ was applied; then, all tube sections inside the square were delimited and the software calculated the total tubular area inside the square, which was used to calculate the corresponding percentages. Tubular variables of the epididymal tissue were obtained by tracing outlines of 10 rounded tube sections in every region for each ram lamb, including and not including the muscular layer, also by tracing the tubular lumen. The analysis software calculated several variables, such as tubular area, perimeter and diameter. Such data were used to calculate the tubular diameter, the thickness and area of the muscular layer, the height and area of the epithelium, and the diameter and area of the tubular lumen in every epididymal region in each lamb. 
luz tubular. El software de análisis calculó diferentes variables, tales como el diámetro, área y perímetro tubular. Además, estos datos se utilizaron para calcular el grosor y el área de la capa muscular, la altura y el área del epitelio, y el diámetro y el área de la luz tubular en todas las regiones del epidídimo en cada cordero.

\section{Análisis estadístico}

Los 10 valores de cada región del epidídimo de cada cordero se promediaron, de esta manera, para cada cordero se obtuvo un valor único para cada región del epidídimo para el análisis estadístico. Los datos se analizaron como un diseño completamente al azar con arreglo factorial, utilizando el procedimiento GLM de SAS (SAS Institute Inc., Cary NC, USA). La edad de los animales, la región anatómica y la interacción edad por región se incluyeron en el modelo; la opción PDIFF de SAS se utilizó para comparar las medias de mínimos cuadrados entre los grupos de edad y entre las regiones. Para cumplir con los supuestos del análisis de varianza, los datos porcentuales, expresados como proporciones ( $p)$, se transformaron al arco-seno de la raíz cuadrada de $\mathrm{p}$; todas las demás variables se transformaron $a \log _{n}$. Después del análisis, los datos se retransformaron a los valores reales para los cuadros y figuras.

\section{RESULTADOS}

\section{Peso de los epidídimos}

La siguiente descripción considera el peso de ambos epidídimos. Las diferencias entre edades para el peso de los epidídimos siempre fueron significativas $(P<0.05)$, excepto 0 vs 3 , y 18 vs 21 semanas. Al nacimiento, el peso de los epidídimos fue de $0.93 \pm 0.07 \mathrm{~g}$ (Figura 1), durante las primeras 9 semanas aumentó 5.4 veces (5 $50.49 \mathrm{~g})$; La mayor tasa de crecimiento se observó entre las semanas 9 y 18 (4.7 veces), hasta llegar a $25.6 \pm 2.5 \mathrm{~g}$ en la semana 21 . La interacción región $x$ edad fue significativa $(P<0.001)$; el peso de cada región

\section{Statistical Analyses}

The 10 values for each epididymal region within a lamb were averaged; in this way a single value for a particular epididymal region and lamb was obtained for the statistical analysis. Data were analyzed as a completely randomized design with a factorial arrangement, using the GLM procedure of SAS (SAS Institute Inc., Cary NC, USA). The age of the animals, the anatomical region and the interaction age by region were included in the model; the PDIFF option of SAS was used to compare least square means among age groups and among regions. In order to meet the assumptions of the analysis of variance, percentage data, expressed as proportions ( $p)$, were transformed to arc-sine squared root of $p$; all the other variables were $\log _{n}$ transformed. After analysis, data were transformed back to actual values for tables and figures.

\section{RESULTS}

\section{Epididymal weight}

Differences between ages for paired epididymis weight were always significant $(P<0.05)$, except for 0 vs 3, and 18 vs 21 wk. At birth, the weight of paired epididymides was $0.93 \pm 0.07 \mathrm{~g}$ (Figure 1), during the first $9 \mathrm{wk}$ increased 5.4 fold $(5 \pm 0.49 \mathrm{~g})$; the greatest growth rate was observed between 9 and 18 wk ( 4.7 fold), until reaching $25.6 \pm 2.5 \mathrm{~g}$ on $w \mathrm{k} 21$. The interaction age $\mathrm{x}$ region was significant $(P<0.001)$; paired weight of each epididymal region followed a similar trend, yet with some differences among regions. Corpus epididymidis was always lighter than cauda $(P<0.01)$, and lighter than caput from wk 6 onwards $(P<0.01)$, from $0.14 \pm$ $0.01 \mathrm{~g}$ at birth to $4.6 \pm 0.31 \mathrm{~g}$ at wk 21. At birth, the weight of caput $(0.34 \pm 0.03 \mathrm{~g})$ and cauda $(0.44 \pm 0.03 \mathrm{~g})$ were not different to each other, as well as by 3 wk. Between 6 and $12 \mathrm{wk}$, the cauda weight increased faster and was greater than caput $(P<0.01)$. After wk 12 , the caput weight started increasing, in such a way that by 15 to $21 \mathrm{wk}$ no differences were detected between the two regions (caput 10.7 $\pm 1.03 \mathrm{~g}$; cauda $10.3 \pm 0.89 \mathrm{~g}$ at wk 21). 
Figura 1. Desarrollo del peso total y de cada región anatómica de ambos epidídimos, del nacimiento a 21 semanas de edad de corderos Barbados Blackbelly

Figure 1. Development of paired epididymal weight and paired weight of each anatomical region, from birth to 21 wk of age in Barbados Blackbelly ram lambs

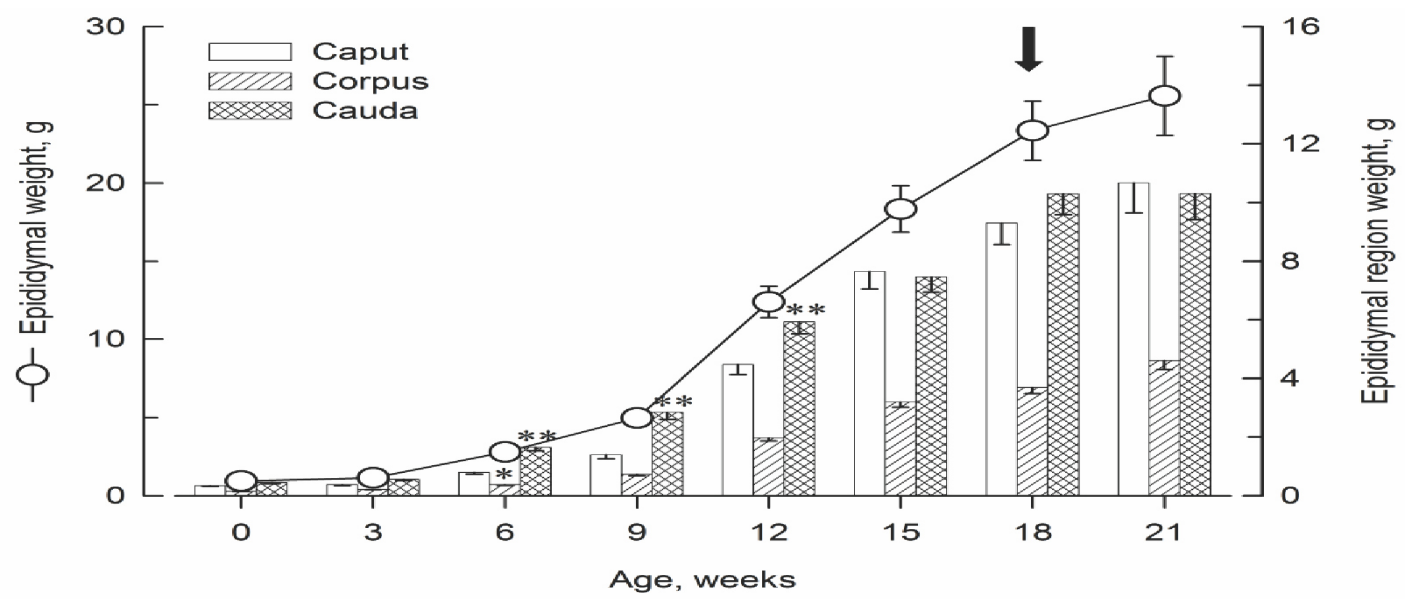

Each time point represent the mean \pm SE for 4 to 6 rams. ${ }^{*}$ Corpus weight was smaller than caput from 6 wk onwards $(P<0.01)$, and smaller than cauda at every age evaluated $(P<0.01)$. ${ }^{* *}$ Cauda weight was larger than caput at 6,9 and 12 wk of age $(P<0.01)$. The arrow indicates the age when sperm first appeared in the tubular lumen of the three epididymal regions.

del epidídimo siguió una tendencia similar (Figura 1), pero con algunas diferencias entre regiones. El cuerpo del epidídimo siempre fue más ligero que la cola $(P<0.01)$, y más ligero que la cabeza de la semana 6 en adelante $(P<0.01)$, de $0.14 \pm 0.01 \mathrm{~g}$ al nacer a $4.6 \pm$ $0.31 \mathrm{~g}$ en la semana 21 . Al nacimiento, el peso de la cabeza $(0.34 \pm 0.03 \mathrm{~g})$ y de la cola $(0.44$ $\pm 0.03 \mathrm{~g}$ ) no fueron diferentes entre sí, al igual que en la semana 3. Entre las semana 6 y 12, el peso de la cola aumentó más rápido y fue mayor que la cabeza $(P<0.01)$. Después de la semana 12 , el peso de la cabeza aumentó, de tal manera que en las semana 15 a 21 no se detectaron diferencias entre las dos regiones (cabeza $10.7 \pm 1.03 \mathrm{~g}$; cola $10.3 \pm 0.89 \mathrm{~g}$ en la semana 21).

El diferente desarrollo de las regiones del epidídimo también fue evidente en el porcentaje que cada región aportó al peso total del órgano (interacción edad $x$ región, $P<0.001$; Figura 2). La proporción aportada por la cabeza disminuyó entre el nacimiento (36.7 \%) y la semana 9
The differential development of the epididymal regions was also evident on the percentage that each region accounted to the total organ weight (interaction age $\mathrm{x}$ region, $P<0.001$; Figure 2). The proportion accounted by the caput decreased between birth (36.7 \%) and wk 9 (28\%; $P<0.001)$, then increased until wk $15(P<0.05)$, with no further changes thereafter until wk 21 (41.7\%). The cauda followed an opposite trend, increasing from birth (47.8\%) to wk 6 (58.5\%; $P<0.001)$, decreasing from wk 9 to $15(P<0.001)$, with no further changes thereafter until wk 21 (40.3\%). Cauda was greater than the other regions from birth to wk $12(P<0.001)$, and not different from caput at wk 15, 18 and 21; corpus accounted always the smallest percentage $(P<0.001)$.

\section{Characteristics of the epididymal tissue}

Tubular tissue percentage and tubular diameter. The interaction age by region was significant $(P<0.05)$ for the percentage of tubular tissue; this variable had an increasing trend in the three epididymal regions until wk 15 (Table 1); 
Figura 2. Desarrollo del porcentaje aportado por cada región anatómica del epidídimo al peso total del órgano, del nacimiento a 21 semanas de edad de corderos Barbados Blackbelly

Figure 2. Development of the percentage accounted by each epididymal region to the total epididymal weight, from birth to 21 wk of age in Barbados Blackbelly ram lambs

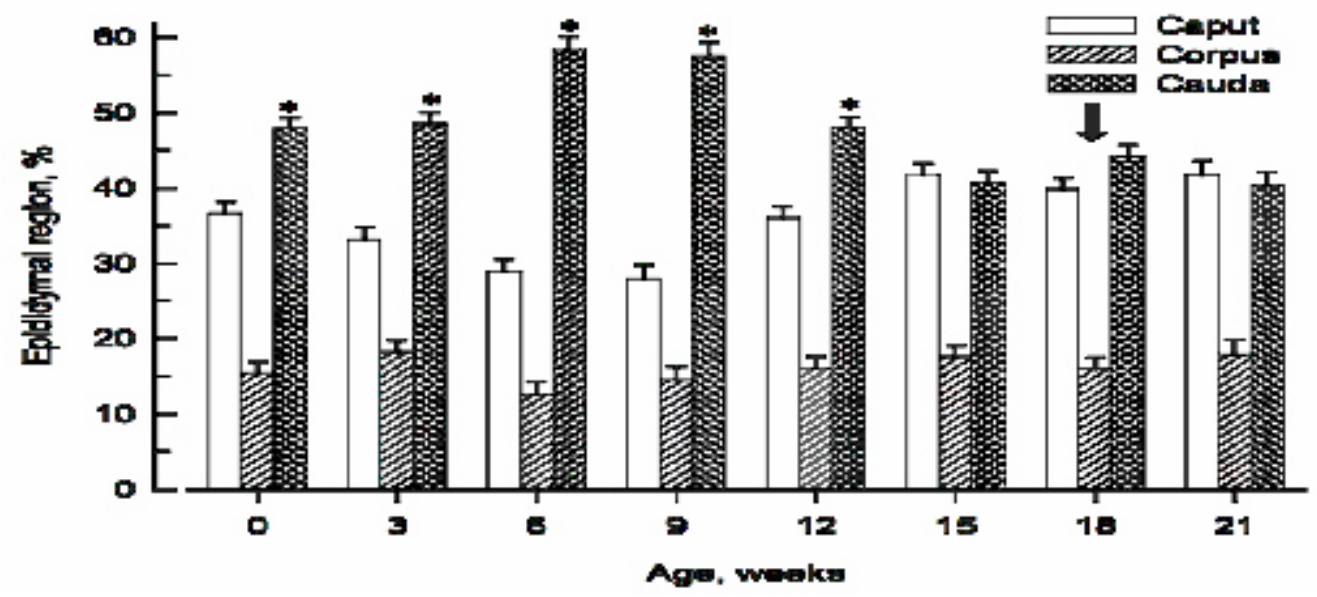

Each time point represents the mean \pm SE for 4 to 6 rams. ${ }^{*}$ Cauda was greater than caput from 0 to 12 wk of age $(P<0.001)$; corpus always accounted for the smaller percentage to the total epididymal weight $(P<0.001)$. The arrow indicates the age when sperm first appeared in the tubular lumen of the three epididymal regions.

(28\%, $P<0.001)$, después aumentó hasta la semana $15(P<0.05)$, sin más cambios a partir de entonces hasta la semana 21 (41.7\%). La cola siguió una tendencia opuesta, aumentó entre el nacimiento (47.8 \%) y la semana 6 (58.5 \%; $P<0.001)$, con una disminución entre las semanas 9 y $15(P<0.001)$, sin más cambios a partir de entonces hasta la semana 21 (40.3\%). La cola fue mayor que las otras regiones desde el nacimiento hasta la semana $12(P<0.001)$, y no fue diferente de la cabeza en las semanas 15,18 y 21 ; el cuerpo siempre aportó el menor porcentaje $(P<0.001)$.

\section{Características del tejido epididimal}

Porcentaje de tejido tubular y diámetro tubular. La interacción edad por región fue significativa $(P<0.05)$ para el porcentaje de tejido tubular; esta variable tuvo una tendencia creciente en las tres regiones del epidídimo hasta la semana 15 (Cuadro 1); después, no cambió (cabeza y cuerpo) o disminuyó (cola) hacia la semana 21. En general, el porcentaje de tejido tubular fue then, it did not change (caput and corpus) or decreased (cauda) by wk 21. Overall, the percentage of tubular tissue was greatest in the cauda and lowest in the caput $(P<0.05)$, except for wk 3, 18 and 21, when no differences among regions were detected; corpus was intermediate, but not always different from the other regions. The increasing rate (percentage of each age, related to wk 21) was different among regions (Figure $3 a$ ); by wk 6 , corpus and cauda had reached, respectively, 93 and $88 \%$ of the final value, whilst caput had reached only $68 \%$, such trend was maintained until wk 15. For tubular diameter, the interaction age by region was not significant $(P=0.13$; Table 1$)$. This variable increased $(P<0.05)$ until wk 15 (caput and corpus) or 12 (cauda), with no changes thereafter. The greatest diameter was always observed in the cauda, and the smallest in the caput $(P<005)$; corpus was not different from caput, except for wk 3 and 6, when all regions were different to each other. Regarding the increasing rate (Figure 3b), by wk 6, caput, 
mayor en la cola y menor en la cabeza $(P<0.05)$, a excepción de las semanas 3, 18 y 21 , cuando no se detectaron diferencias entre las regiones; el cuerpo fue intermedio, pero no siempre fue diferente de las otras regiones. La tasa de incremento (porcentaje de cada edad, con corpus and cauda had reached 38, 47 and $55 \%$ of their final values, respectively; similar differences were maintained until wk 12, at that age cauda had reached $92 \%$, whilst similar percentages (90\%) were not reached in caput and corpus until 18 wk of age.

Cuadro 1. Medias $( \pm \mathrm{EE})$ del porcentaje de tejido tubular y del diámetro tubular promedio en las diferentes regiones anatómicas del epidídimo de corderos Barbados Blackbelly, del nacimiento a 21 semanas de edad

Table 1. Mean $( \pm \mathrm{SE})$ of the percentage of tubular tissue and the average tubular diameter in the several epididymal anatomical regions in Barbados Blackbelly ram lambs, from birth to 21 wk of age

\begin{tabular}{|c|c|c|c|c|c|c|}
\hline \multirow{2}{*}{$\begin{array}{l}\text { Age } \\
\text { (wk) }\end{array}$} & \multicolumn{3}{|c|}{ Tubular tissue (\%) } & \multicolumn{3}{|c|}{ Tubular diameter $(\mu \mathrm{m})$} \\
\hline & Caput & Corpus & Cauda & Caput & Corpus & Cauda \\
\hline 0 & a38.6 $\pm 3.4 y$ & $\mathrm{a} 34.6 \pm 3.4 \mathrm{y}$ & a50.2 $\pm 3.4^{z}$ & $a 90 \pm 15 y$ & $\mathrm{a} 101 \pm 15 \mathrm{y}$ & $a 149 \pm 15^{z}$ \\
\hline 3 & $a b 42.5 \pm 3.49 z$ & b51.7 $\pm 3.4^{z}$ & $a 50 \pm 3.4 z$ & $\operatorname{abg} 2 \pm 15^{x}$ & $\mathrm{~b} 120 \pm 15 y$ & $a 162 \pm 15 z$ \\
\hline 6 & $a b c 52.3 \pm 3.82 y$ & ${ }^{\mathrm{c}} 64.7 \pm 3.82^{z}$ & $\mathrm{~b}_{68.4} \pm 3.82^{z}$ & $b 107 \pm 16^{x}$ & $b c 136 \pm 16 y$ & $b_{227} \pm 16 z$ \\
\hline 9 & bc52.7 $\pm 4.27 y$ & ${ }^{c} 64.8 \pm 4.27 \mathrm{yz}$ & b $66.1 \pm 4.27 z$ & $c 134 \pm 18 y$ & $\mathrm{c} 157 \pm 18 \mathrm{y}$ & ${ }^{c} 299 \pm 18 z$ \\
\hline 12 & $\operatorname{cd} 56.9 \pm 3.49 y$ & ${ }^{c} 64.4 \pm 3.49 y$ & b76.9 $\pm 3.49 z$ & $d_{192} \pm 15 y$ & $d_{223} \pm 15 y$ & $d 380 \pm 15 z$ \\
\hline 15 & $\mathrm{e} 74.6 \pm 3.49 \mathrm{y}$ & d77.8 $\pm 3.49 y$ & $c 86.8 \pm 3.49 z$ & $\mathrm{e}_{248} \pm 15 \mathrm{y}$ & de $249 \pm 15 y$ & $d 396 \pm 15 z$ \\
\hline 18 & $\operatorname{de} 66.8 \pm 3.49 z$ & bc60.2 $\pm 3.49 z$ & b70.1 $\pm 3.49 z$ & $\mathrm{e}_{248} \pm 15 \mathrm{y}$ & $\mathrm{e}_{275} \pm 15 \mathrm{y}$ & $d_{421} \pm 15^{z}$ \\
\hline 21 & $\mathrm{e} 76.6 \pm 4.27 \mathrm{z}$ & $\operatorname{cd} 69.7 \pm 4.27 z$ & b77. $6 \pm 4.27 z$ & $\mathrm{e} 283 \pm 18 \mathrm{y}$ & $\mathrm{e}_{291} \pm 18 \mathrm{y}$ & $\mathrm{d} 405 \pm 18 z$ \\
\hline
\end{tabular}

a-e Means within a column without a common superscript are different $(P<0.05)$.

$x, y, z$ Means within a row and variable without a common superscript are different $(P<0.05)$.

Figura 3. Tasa de incremento relativo del porcentaje de tejido tubular (panel a), diámetro tubular (panel b), altura del epitelio (panel c) y área del epitelio (panel d) en corderos Barbados Blackbelly

Figure 3. Relative increase of the epididymal tubular tissue percentage (panel a), tubular diameter (panel b), epithelium height (panel c) and epithelium area (panel d) in Barbados Blackbelly ram lambs
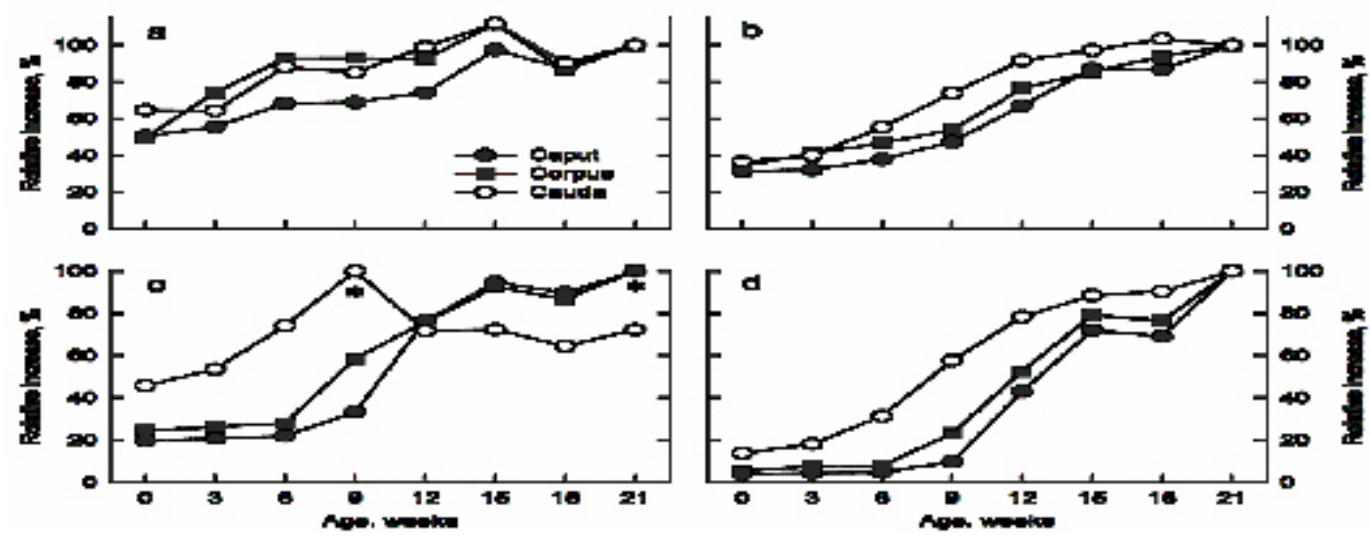

Data are the percentage of the values at each age as compared with the value at 21 wk of age for each variable (panels a, b, d). * For epithelium height (panel $\mathrm{c}$ ), the percentage value at each age is relative to the maximum value reached in each region ( $21 \mathrm{wk}$ for caput and corpus, and 9 wk for cauda). 
relación a la semana 21 ) fue diferente entre las regiones (Figura 3a); en la semana 6, el cuerpo y la cola habían alcanzado, respectivamente, el 93 y el $88 \%$ del valor final, mientras que la cabeza alcanzó sólo el $68 \%$, tal tendencia se mantuvo hasta la semana 15. Para el diámetro tubular, la interacción edad por región no fue significativa $(P=0.13$; Cuadro 1$)$. Esta variable aumentó $(P<0.05)$ hasta la semana 15 (cabeza y cuerpo) o 12 (cola), sin cambios a partir de entonces. El mayor diámetro siempre se observó en la cola, y el menor en la cabeza $(P<0.05)$; el cuerpo no fue diferente de la cabeza, a excepción de las semanas 3 y 6 , cuando todas las regiones fueron diferentes entre sí. En cuanto a la tasa de incremento (Figura 3b), en la semana 6, la cabeza, el cuerpo y la cola habían alcanzado, respectivamente, 38, 47 y $55 \%$ de sus valores finales; diferencias similares se mantuvieron hasta la semana 12; a esa edad la cola había alcanzado el $92 \%$, mientras que porcentajes similares (90 \%) no se alcanzaron en la cabeza y el cuerpo hasta las 18 semanas de edad.

Capa muscular del epidídimo. La interacción edad por región fue significativa $(P<0.01)$ para ambas variables de la capa muscular. El grosor
Epididymal muscular layer. The interaction age by region was significant $(P<0.01)$ for both variables of the muscular layer. The thickness of the muscular layer in caput did not change between birth and wk 6 (Table 2), increased $35 \%$ by wk $9(P<0.05)$ and then, did not change or had a descendent trend until wk 21 . In the cauda, the muscular thickness did not change between birth and wk 6, increased $119 \%$ by wk $9(P<0.05)$, with no change by wk 15 and a descendent trend thereafter $(P<0.05)$. In the corpus epididymidis there were no changes between 3 and 21 wk. When comparing the muscular layer thickness in wk 0 vs wk 21, no differences were observed in the caput and corpus, but in the cauda, it was $48 \%$ greater on wk $21(P<0.05)$. The muscular layer area (Table 2) increased until wk 12 (caput and corpus) and 9 (cauda), with no significant changes thereafter. The maximum area observed in each region, as compared to value at birth, was 3.8-, 3.8-, and 5.5-fold, for caput (wk 18), corpus (wk 18) and cauda (wk 15), respectively. Comparisons among regions were similar for both variables, the greatest values were observed in the cauda $(P<0.05)$, followed by the corpus and caput; however, differences between the last two were significant $(P<0.05)$ only at 3 and 6 wk.

Cuadro 2. Medias $( \pm \mathrm{EE})$ del grosor y área de la capa muscular del tubo en las diferentes regiones anatómicas del epidídimo de corderos Barbados Blackbelly, del nacimiento a 21 semanas de edad

Table 2. Mean $( \pm \mathrm{SE})$ of the thickness and area of the tubular muscular layer in the several epididymal anatomical regions in Barbados Blackbelly ram lambs, from birth to 21 wk of age

\begin{tabular}{|c|c|c|c|c|c|c|}
\hline \multirow{2}{*}{$\begin{array}{l}\text { Age } \\
\text { (wk) }\end{array}$} & \multicolumn{3}{|c|}{ Thickness of muscular layer $(\mu \mathrm{m})$} & \multicolumn{3}{|c|}{ Area of muscular layer $\left(\mu \mathrm{m}^{2}\right)$} \\
\hline & Caput & Corpus & Cauda & Caput & Corpus & Cauda \\
\hline 0 & $\mathrm{a} 17.3 \pm 2.4 \mathrm{y}$ & $\mathrm{a} 19.2 \pm 2.4 \mathrm{y}$ & $\mathrm{a} 27.4 \pm 2.4 \mathrm{z}$ & $a 4,847 \pm 3,392 y$ & $a 5,870 \pm 3,392 y$ & $a 12,096 \pm 3,392^{z}$ \\
\hline 3 & $\mathrm{a} 17.3 \pm 2.2^{\mathrm{x}}$ & ab22.9 $\pm 2.4 y$ & $\mathrm{a} 29.1 \pm 2.4 \mathrm{z}$ & $a 4,798 \pm 3,392^{x}$ & b8,028 $\pm 3,392 y$ & $\mathrm{a} 14,210 \pm 3,392^{2}$ \\
\hline 6 & $a b 17.3 \pm 2.6^{x}$ & $\mathrm{ab} 22.8 \pm 2.7 \mathrm{y}$ & $a b 34.7 \pm 2.6^{z}$ & $a 4,798 \pm 3,716^{x}$ & b8,003 $\pm 3,716 y$ & $b_{21,775 \pm 3,716^{z}}$ \\
\hline 9 & $\mathrm{c} 23.4 \pm 2.9 y$ & $\mathrm{ab} 21.6 \pm 3.0 \mathrm{y}$ & $\mathrm{d} 59.2 \pm 2.9 z$ & $b 9,261 \pm 4,155 y$ & $\mathrm{~b} 10,676 \pm 4,155 \mathrm{y}$ & $c 50,836 \pm 4,155^{z}$ \\
\hline 12 & $\mathrm{bc} 21.4 \pm 2.4 \mathrm{y}$ & $\mathrm{b} 23.5 \pm 2.4 \mathrm{y}$ & $\operatorname{cd} 51.8 \pm 2.4^{z}$ & $c 13,276 \pm 3,392 y$ & $c 16,698 \pm 3,392 y$ & ${ }^{c} 66,328 \pm 3,392^{z}$ \\
\hline 15 & $c 22.1 \pm 2.4 \mathrm{y}$ & $a b 23.1 \pm 2.4 y$ & $\operatorname{cd} 50.7 \pm 2.4 z$ & $c 16,998 \pm 3,392 y$ & $c 18,365 \pm 3,392 y$ & $c 64,453 \pm 3,392^{2}$ \\
\hline 18 & $a b c 21.2 \pm 2.4 y$ & $\mathrm{~b}_{2} 24.5 \pm 2.4 \mathrm{y}$ & $b_{37.9} \pm 2.4 z$ & $c 17,510 \pm 3,392 y$ & $c 21,037 \pm 3,392 y$ & $c 51,495 \pm 3,392^{z}$ \\
\hline 21 & $\mathrm{a} 16.9 \pm 2.9 \mathrm{y}$ & ab $20.9 \pm 3.0 y$ & $\mathrm{bc} 41 \pm 2.9 z$ & $c 16,085 \pm 4,155 y$ & ${ }^{c} 20,638 \pm 4,155 y$ & $c 56,418 \pm 4,155^{2}$ \\
\hline
\end{tabular}

a-e Means within a column without a common superscript are different $(P<0.05) . x, y, z$ Means within a row and variable without a common superscript are different $(P<0.05)$. 
de la capa muscular en la cabeza no cambió entre el nacimiento y la semana 6 (Cuadro 2), aumentó $35 \%$ en la semana $9(P<0.05)$, posteriormente no cambió o tuvo una tendencia descendente hasta la semana 21 . En la cola, el grosor de la capa muscular no cambió entre el nacimiento y la semana 6, aumentó $119 \%$ en la semana $9(P<0.05)$, sin cambios hacia la semana 15 y una tendencia descendente a partir de entonces $(P<0.05)$. En el cuerpo del epidídimo no hubo cambios entre la semana 3 y 21. Al comparar el grosor de la capa muscular en la semana 0 vs 21, no se observaron diferencias en la cabeza y cuerpo, pero en la cola fue $48 \%$ mayor en la semana $21(P<0.05)$. El área de la capa muscular (Cuadro 2) aumentó hasta la semana 12 (cabeza y cuerpo) y 9 (cola), sin cambios significativos a partir de entonces; El área máxima observada en cada región, en comparación con el valor al nacimiento, fue 3.8, 3.8 y 5.5 veces, para cabeza (semana 18), cuerpo (semana 18) y cola (semana 15), respectivamente. Las comparaciones entre regiones fueron similares en ambas variables, los mayores valores se observaron en la cola $(P<0.05)$, seguido por el cuerpo y la cabeza; sin embargo, las diferencias entre los dos últimos fueron significativas $(P<0.05)$ solamente en las semanas 3 y 6.

Epitelio del epidídimo. La interacción edad por región fue significativa $(P<0.001)$ para ambas variables de la capa epitelial. En la cabeza y cuerpo, la altura del epitelio no cambió entre el nacimiento y la semana 6, luego aumentó hasta la semana 12 (cabeza) o 15 (cuerpo), sin más cambios (Cuadro 3); en la cola, se observó una tendencia creciente desde el nacimiento hasta la semana 9, seguido de una disminución en la semana 12 , sin más cambios hasta la semana 21. La comparación entre regiones tuvo dos fases diferentes, del nacimiento a la semana 9, el epitelio fue más alto en la cola y más bajo en la cabeza $(P<0.05)$, pero de la semana 12 a la 21 la situación se invirtió, ya que los valores más bajos se observaron en la cola $(P<0.05)$ y los mayores en la cabeza y cuerpo, sin diferencias entre estos dos. En cuanto a la tasa
Epididymal epithelium. The interaction age by region was significant $(P<0.001)$ for both variables of the epithelial layer. In the caput and corpus, the epithelium height did not change between birth and wk 6, then increased until wk 12 (caput) or 15 (corpus), with no further changes (Table 3); in the cauda, an increasing trend was observed from birth to wk 9, then, decreased on wk 12, with no more changes until wk 21. Comparison between regions had two different phases, from birth to wk 9, the epithelium was highest in the cauda and lowest in the caput $(P<0.05)$, but from 12 to $21 \mathrm{wk}$ the situation reversed, as the lowest values were observed in the cauda $(P<0.05)$ and the greatest in the caput and corpus with no differences between the last two. Regarding the increasing rate (Figure 3c), at birth, cauda had over $45 \%$ of their maximum value, which was reached at wk 9; caput and corpus, at birth had reached, respectively, 20 and $25 \%$ of the value at wk 21 , and did not reach over $90 \%$ until wk 15. The epithelial area (Table 3) did not change between birth and wk 6 (caput and corpus) or 3 (cauda), then, it increased until wk 15 in the three regions $(P<0.05)$, with no further changes (Table 3). Between birth and wk 12, the greatest values were observed in the cauda, with the smallest values in the caput $(P<0.05)$; from wk 15 onwards no differences among regions were detected. The increasing rate was always greater for cauda (Figure 3d), by wk 6 it had reached $31 \%$, as compared with 5 and $8 \%$ for caput and corpus, respectively; such differences were maintained until wk 18.

Epididymal tubular lumen. The interaction age by region was not significant $(P \geq 0.25)$ for both variables of the tubular lumen, but the effect of region was $(P<0.001)$. The lumen diameter and area did not increase or increased very little in all three regions until wk 6; then, increased steadily until wk 15 (caput and corpus) or 12 (cauda), with no further changes thereafter (Table 4). The greatest relative augment was observed between 9 and $12 \mathrm{wk}$ (0.5- to 1.2 -fold in the lumen diameter, and 
Cuadro 3. Medias ( $\pm \mathrm{EE}$ ) de la altura y el área del epitelio tubular en las diferentes regiones anatómicas del epidídimo de corderos Barbados Blackbelly, del nacimiento a 21 semanas de edad

Table 3. Mean ( \pm SE) of the tubular epithelium height and area in the several epididymal anatomical regions in Barbados Blackbelly ram lambs, from birth to 21 wk of age

\begin{tabular}{|c|c|c|c|c|c|c|}
\hline \multirow{2}{*}{$\begin{array}{l}\text { Age } \\
\text { (wk) }\end{array}$} & \multicolumn{3}{|c|}{ Epithelium height $(\mu \mathrm{m})$} & \multicolumn{3}{|c|}{ Epithelium area $\left(\mu \mathrm{m}^{2}\right)$} \\
\hline & Caput & Corpus & Cauda & Caput & Corpus & Cauda \\
\hline 0 & ag. $8 \pm 2.4^{x}$ & $\mathrm{a} 14.2 \pm 2.4 \mathrm{y}$ & $a 19.9 \pm 2.4^{z}$ & $a 1,616 \pm 2,218^{x}$ & a2,330 $\pm 2,218 y$ & $a 5,182 \pm 2,218^{z}$ \\
\hline 3 & $\mathrm{a} 10.3 \pm 2.4^{\mathrm{x}}$ & $\mathrm{a} 14.9 \pm 2.4 \mathrm{y}$ & $a b 24.6 \pm 2.4^{z}$ & $a 1,719 \pm 2,218^{x}$ & $a 3,180 \pm 2,218 y$ & $a 7,337 \pm 2,218^{z}$ \\
\hline 6 & $\mathrm{a} 10.4 \pm 2.6^{\mathrm{x}}$ & $a_{1} 15.2 \pm 2.6 y$ & $\mathrm{~cd}_{32.1 \pm 2.6^{z}}$ & $a 1,720 \pm 2,430^{x}$ & a3,221 $\pm 2,430 y$ & $b_{11}, 986 \pm 2,430 z$ \\
\hline 9 & $\mathrm{~b} 16.2 \pm 2.9 \mathrm{y}$ & b32.1 $\pm 2.9 z$ & $\mathrm{~d} 43.1 \pm 2.9 \mathrm{z}$ & $b 3,800 \pm 2,717 x$ & b9,987 $\pm 2,717 y$ & $c 21,483 \pm 2,717 z$ \\
\hline 12 & $\mathrm{c} 37 \pm 2.3 \mathrm{yz}$ & $b c 42.4 \pm 2.3 z$ & $c 31 \pm 2.3 y$ & $c 16,910 \pm 2,218 y$ & $c 22,105 \pm 2,218 y z$ & $\operatorname{cd} 29,720 \pm 2,218^{z}$ \\
\hline 15 & $c 44.8 \pm 2.3 z$ & $c 50.4 \pm 2.3 z$ & $c 31.2 \pm 2.3 y$ & $d 26,545 \pm 2,218 z$ & $d 32,374 \pm 2,218^{z}$ & $d 33,531 \pm 2,218^{z}$ \\
\hline 18 & $c 42.6 \pm 2.3^{z}$ & $c 47.1 \pm 2.3^{z}$ & $b_{c} 28 \pm 2.3 y$ & $d_{26,288} \pm 2,218^{z}$ & d $31,905 \pm 2,218^{z}$ & $d 33,766 \pm 2,218^{z}$ \\
\hline 21 & $c 47.5 \pm 2.8^{z}$ & $c 54.6 \pm 2.8^{z}$ & $c 31.8 \pm 2.8 y$ & $d 36,119 \pm 2,717 z$ & $d 40,755 \pm 2,717 z$ & $d 37,240 \pm 2,717 z$ \\
\hline
\end{tabular}

a-d Means within a column without a common superscript are different $(P<0.05)$.

$x, y, z$ Means within a row and variable without a common superscript are different $(P<0.05)$.

de incremento (Figura 3c), al nacer la cola tenía más del $45 \%$ de su valor máximo, que se alcanzó en la semana 9; la cabeza y el cuerpo al nacer habían alcanzado, respectivamente, el 20 y $25 \%$ del valor de la semana 21 , y no rebasaron el $90 \%$ hasta la semana 15 . El área epitelial (Cuadro 3) no cambió entre el nacimiento y la semana 6 (cabeza y cuerpo) o
1.3- to 5.2-fold in the lumen area), with the greatest increase in the cauda; both variables were greatest in the cauda at all ages $(P<0.05)$, with no differences between caput and corpus. The maximum lumen diameter observed in each region (caput, corpus and cauda, respectively) corresponded to 3.7-, 3.5- and 5.2-fold increase, as compared to wk 0 . Similarly, the increase in

Cuadro 4. Medias $( \pm \mathrm{EE})$ del diámetro y área de la luz tubular en las diferentes regiones anatómicas del epidídimo de corderos Barbados Blackbelly, del nacimiento a 21 semanas de edad

Table 4. Mean ( \pm SE) of the tubular lumen diameter and area in the several epididymal anatomical regions in Barbados Blackbelly ram lambs, from birth to 21 wk of age

\begin{tabular}{|c|c|c|c|c|c|c|}
\hline \multirow{2}{*}{$\begin{array}{l}\text { Age } \\
\text { (wk) }\end{array}$} & \multicolumn{3}{|c|}{ Lumen diameter $(\mu \mathrm{m})$} & \multicolumn{3}{|c|}{ Lumen area $\left(\mu \mathrm{m}^{2}\right)$} \\
\hline & Caput & Corpus & Cauda & Caput & Corpus & Cauda \\
\hline 0 & a $36 \pm 14.5 y$ & a35 $\pm 14.5 y$ & a58 $\pm 14.5^{z}$ & $a 1,524 \pm 6,372 y$ & $a 1,385 \pm 6,372 y$ & $a 4,152 \pm 6,372^{z}$ \\
\hline 3 & ab37 $\pm 14.5 y$ & ab44 $\pm 14.5 y z$ & a54 $\pm 14.5^{z}$ & $a b 1,455 \pm 6,372 y$ & $\mathrm{~b} 2,346 \pm 6,372 \mathrm{yz}$ & $a 3,309 \pm 6,372^{z}$ \\
\hline 6 & $a b 36 \pm 15.9 y$ & $b_{53} \pm 15.9 y z$ & $a b 73 \pm 15.9 z$ & $a b 1,755 \pm 6,980 y$ & b2,994 $\pm 6,980 y z$ & $a b 5,629 \pm 6,980^{z}$ \\
\hline 9 & $\mathrm{bc} 50 \pm 17.7 \mathrm{y}$ & b50 $\pm 17.7 y$ & b94 $\pm 17.7 z$ & 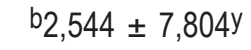 & $\mathrm{b}_{2,411 \pm 7,804 \mathrm{y}}$ & b8,929 $\pm 7,804^{z}$ \\
\hline 12 & $c 75 \pm 14.5 y$ & $\operatorname{cg} 1 \pm 14.5 y$ & $c 216 \pm 14.5^{z}$ & ${ }^{c} 6,432 \pm 6,372 y$ & $c 8,489 \pm 6,372 y$ & $c 57,784 \pm 6,372^{z}$ \\
\hline 15 & $\mathrm{~d} 114 \pm 14.5 \mathrm{y}$ & $\operatorname{cd} 102 \pm 14.5 y$ & $c 232 \pm 14.5 z$ & $d 13,803 \pm 6,372 y$ & $\operatorname{cd} 12,507 \pm 6,372 y$ & $c 64,620 \pm 6,372^{z}$ \\
\hline 18 & $\mathrm{~d}_{121} \pm 14.5 \mathrm{y}$ & $\operatorname{cd} 132 \pm 14.5 y$ & $c 289 \pm 14.5^{z}$ & $d_{16,138} \pm 6,372 y$ & $\operatorname{cd} 19,469 \pm 6,372^{y}$ & $\mathrm{c} 89,408 \pm 6,372^{z}$ \\
\hline 21 & $\mathrm{~d} 154 \pm 17.7 \mathrm{y}$ & $\mathrm{d} 140 \pm 17.7 \mathrm{y}$ & $\mathrm{c} 260 \pm 17.7 \mathrm{z}$ & $\mathrm{d} 26,890 \pm 7,804 \mathrm{y}$ & $\mathrm{d}_{20,791 \pm 7,804 y}$ & $\mathrm{c} 82,177 \pm 7,804 \mathrm{z}$ \\
\hline
\end{tabular}

a-d Means within a column without a common superscript are different $(P<0.05)$.

$y, z$ Means within a row and variable without a common superscript are different $(P<0.05)$. 
3 (cola), seguido de un incremento hasta la semana 15 en las tres regiones $(P<0.05)$, sin más cambios posteriores (Cuadro 3 ). Entre el nacimiento y la semana 12 , los mayores valores se observaron en la cola, con los menores valores en la cabeza $(P<0.05)$; desde la semana 15 en adelante no se detectaron diferencias entre las regiones. La tasa de incremento fue siempre mayor en la cola (Figura 3d), hacia la semana 6 ya había alcanzado el $31 \%$, en comparación con el 5 y $8 \%$ de la cabeza y el cuerpo, respectivamente; estas diferencias se mantuvieron hasta la semana 18.

Luz tubular del epidídimo. La interacción edad por región no fue significativa $(P \geq 0.25)$ para ambas variables de la luz tubular, pero sí el efecto de la región $(P<0.001)$. El diámetro y el área de la luz no aumentaron o aumentaron muy poco en las tres regiones hasta la semana 6 ; a partir de entonces, aumentaron constantemente hasta la semana 15 (cabeza y cuerpo) o 12 (cola), sin más cambios (Cuadro 4). El mayor aumento relativo se observó entre las semanas 9 y $12(0.5$ a 1.2 veces en el diámetro de la luz, y 1.3 a 5.2 veces en el área de la luz), con el mayor aumento en la cola; ambas variables fueron mayores en la cola en todas las edades $(P<0.05)$, sin diferencias entre cabeza y cuerpo. El máximo diámetro de la luz observado en cada región (cabeza, cuerpo y cola, respectivamente) correspondió a un aumento de $3.7,3.5$ y 5.2 veces, en comparación con la semana 0 . Del mismo modo, el aumento en el área de la luz representó $21.8,21.2$ y 24.9 veces, en comparación con la semana 0, para la cabeza, cuerpo y cola, respectivamente. Los espermatozoides aparecieron por primera vez en la luz tubular de las tres regiones del epidídimo en la semana 18 (flechas en las Figuras 1 y 2), lo cual indica que a esa edad los corderos ya habían alcanzado o estaban muy cerca de alcanzar la pubertad.

\section{DISCUSIÓN}

El crecimiento de los epidídimos siguió una tendencia paralela al desarrollo de los testículos, the lumen area represented 21.8-, 21.2- and 24.9-fold, as compared to wk 0 , for caput, corpus and cauda, respectively. Sperm first appeared in the tubular lumen of the three epididymal regions by wk 18 (arrows in Figures 1 and 2), which indicate that by that age the lambs had already reached or were very close to reach puberty.

\section{DISCUSSION}

Epididymal growth followed a parallel trend to testis development, as reported previously for Blackbelly ram lambs(10); the greatest relative epididymal growth was observed between 9 and $18 \mathrm{wk}$, which agrees temporally with the greatest rate of testicular growth in this breed $(10,11)$. During that stage of development, the absolute increase of the interstitial tissue in the testis is associated with increased number of Leydig cells and with the development of their steroidogenic capacity(12). This, in turn, leads to increased plasma concentrations of testosterone $(10,13)$ and, therefore, to greater stimulation to the epididymides, as the development and function of these organs depend on adequate androgen contribution $(14,15)$.

The functional component of the epididymis is the tubular tissue, as all the changes related to sperm maturation and storage during their transit through the epididymis take place in the luminal compartment, under a highly specialized microenvironment consequence of the epithelial activity $(4,5)$. To accomplish this task, the epithelium must be structured in a way such that prevent and regulate the entry of substances into the lumen, it has the ability of synthesize, secrete and absorb components, and it is arranged so that the sperm come into contact with the appropriate environment at the appropriate time(16). It is, therefore, reasonable to consider the variables related to tubular tissue and epithelial layer as the most appropriate to evaluate the epididymal development at the microscopic level; such variables have been used to evaluate epididymal function in several experimental models $(15,17,18)$. 
de acuerdo a lo publicado para corderos Blackbelly(10); el mayor crecimiento relativo de los epidídimos se observó entre las 9 y 18 semanas de edad, lo que coincide con la mayor tasa de crecimiento testicular en esta raza(10,11). Durante esa fase de desarrollo, el aumento absoluto del tejido intersticial en los testículos se asocia con aumento en el número de células de Leydig y con el desarrollo de su capacidad esteroidogénica(12); esto, a su vez, conduce a un aumento en las concentraciones plasmáticas de testosterona $(10,13)$ y por lo tanto a una mayor estimulación de lo epidídimos, ya que el desarrollo y la función de estos órganos depende del aporte adecuado de andrógenos $(14,15)$.

El componente funcional del epidídimo es el tejido tubular, ya que todos los cambios relacionados con la maduración y almacenamiento de los espermatozoides durante su tránsito por el epidídimo se llevan a cabo en el compartimiento luminal, dentro de un microambiente altamente especializado, consecuencia de la actividad epitelial $(4,5)$. Para lograr esta tarea, el epitelio debe estar estructurado de tal manera que pueda prevenir y regular la entrada de sustancias a la luz, además de tener la capacidad de sintetizar, secretar y absorber componentes, permitiendo que los espermatozoides entren en contacto con el entorno adecuado y en el momento exacto(16). Por lo tanto, es razonable considerar las variables relacionadas con el tejido tubular y la capa epitelial como las más convenientes para evaluar el desarrollo epididimal a nivel microscópico; tales variables se han utilizado para evaluar la función del epidídimo en varios modelos experimentales $(15,17,18)$.

A nivel macroscópico (peso y contribución relativa al peso total del órgano), el desarrollo de las diversas regiones anatómicas de los epidídimos siguieron una tendencia diferente entre ellos; la cola del epidídimo comenzó a desarrollarse a una edad muy temprana (semana 6), mientras que el mayor desarrollo de la cabeza y el cuerpo inició en la semana 12. Los hallazgos en el presente estudio, tanto en el
At the macroscopic level (weight and relative contribution to the whole organ weight), the development of the several anatomical regions of the epididymides followed a different trend to each other; the cauda epididymidis began to develop at a very early age (wk 6), whereas the greatest development of the caput and corpus started by wk 12 . The findings in the present study, at both, the macroscopic and microscopic levels, suggest that the postnatal development of the epididymides goes from the cauda towards the caput, which agrees with data reported for other species, such as cattle(19), goats(17) and rats(16). In sheep there is some discrepancy in this matter; whereas some authors reported a trend similar to that observed in the present study $(8)$, others $(9)$ found a maturation process advancing from caput to cauda. It is highly probable that the age of the experimental animals used in the different studies in lambs had accounted for the variation of the results observed among studies. In the study of Bielli(9), ram lambs were older (90 to $180 \mathrm{~d}$-old, that is, 12.9 to $25.7 \mathrm{wk}$ ), as compared with lambs in the study of Nilnophakoon(8) (1 to $18 \mathrm{wk}$ ) and ours (birth to $21 \mathrm{wk}$ ). This fact determines important differences in the stage of physiological maturity of the lambs at the beginning of those studies, as important anatomical and physiological changes occur in the testes and epididymides before $12 \mathrm{wk}$ of age $(10,13)$.

Epididymal function does not depend only on the endocrine stimulation received from testosterone in blood; even more important might be the lumicrine system $(7,15)$, given by testosterone and other factors $(15,16)$. Testosterone, bound to the androgen binding protein (ABP), reaches the epididymides via the efferent ducts, where it is converted into dihydrotestosterone(20). In addition, several growth factors contained in the tubular fluid have important effects on epididymal function $(15,16,21)$; these factors are produced by the Sertoli cells in the seminiferous tubules(22), and carried towards the epididymides via the excurrent duct system. Then, fluid composition undergoes modifications as travels 
nivel macroscópico como en el microscópico, sugieren que el desarrollo posnatal de los epidídimos va en dirección de la cola hacia la cabeza, lo cual coincide con lo publicado para otras especies, tales como bovinos(19), cabras(17) y ratas(16). En los ovinos existe cierta discrepancia en este asunto; mientras que algunos autores observaron una tendencia similar a la encontrada en el presente estudio(8), otros $(9)$ reportaron que el proceso de maduración avanzó en dirección de la cabeza a la cola. Es muy probable que la edad de los animales experimentales utilizados en los diferentes estudios explique la variación de los resultados observados. En el estudio de Bielli(9), los corderos eran mayores (90 a 180 días de edad, es decir, 12.9 a 25.7 semanas), en comparación con los corderos del estudio de Nilnophakoon(8) (1 a 18 semanas) y el presente (nacimiento a 21 semanas). Este hecho determina diferencias importantes en el estado de madurez fisiológica de los corderos al inicio de los estudios, ya que entre el nacimiento y 12 semanas de edad se producen cambios anatómicos y fisiológicos muy importantes en los testículos y epidídimos $(10,13)$.

La función del epidídimo no depende únicamente de la estimulación endocrina recibida por la testosterona sanguínea; aún más importante podría ser el llamado sistema lumicrino $(7,15)$, dado por la testosterona y otros factores $(15,16)$. La testosterona, unida a la proteína ligadora de andrógenos (ABP), llega a los epidídimos vía los conductos eferentes, donde se convierte en dihidrotestosterona(20). Adicionalmente, varios factores de crecimiento contenidos en el fluido tubular tienen efectos importantes sobre la función del epidídimo $(15,16,21)$; estos factores se producen en las células de Sertoli, dentro de los túbulos seminíferos(22) y son transportados a los epidídimos a través del sistema de conductos. Posteriormente, la composición del fluido sufre modificaciones conforme viaja por el epidídimo $(5,16)$. Tal regulación lumicrina es posible sólo después de que aparece la luz de los túbulos seminíferos, como resultado del aumento de la secreción de líquido por las células de Sertoli, cuando inician el proceso de through the epididymal $\operatorname{duct}(5,16)$. Such lumicrine regulation is feasible only after the seminiferous tubule lumen appears, as result of increased fluid secretion by Sertoli cells, when they initiate the maturation process to acquire their functional capacity as adult cells(22). In Blackbelly ram lambs the lumen of the seminiferous tubules appears after $9 \mathrm{wk}$ of age, and by wk 12 lumen is present in $80 \%$ of the tubules(10). This finding also coincides temporarily with the greatest increase in epididymal weight, and with the greatest increase of the epithelium height in the caput and corpus epididymidis observed in the present study, which is in agreement with previous reports in sheep(8) and goats(23).

Cauda epididymidis began to develop before the accelerated growth of the testes(10). At that time, there is still no contribution of tubular fluid via the testicular excurrent duct system, because the lumen of the seminiferous tubules has not formed yet(10). Such findings suggest that the initial development of the cauda epididymidis could not depend on the presence of testosterone or other luminal factors coming from the testicular tubular system. Additional evidences supporting this possibility have been presented in studies with mature goats, whose efferent ducts had been ligated(23); in these goats, it was evident the lack of morphologic and functional dependence of the cauda epididymidis towards the secretions coming from the testis, via the extra testicular excurrent duct system(23). When cauda epididymidis began to develop, plasma concentration of testosterone must have been still very small $(10,13)$; therefore, initial caudal development might not depend on high testosterone concentrations, or depend on other predominant steroids different from testosterone, such as androstenedione, whose circulating concentrations are larger at that age $(24,25,26)$. Another possibility is that the threshold of the caudal response to testosterone and other circulating androgens might be lower at that age. 
maduración para adquirir la capacidad funcional como células adultas(22). En corderos Blackbelly la luz de los túbulos seminíferos aparece después de las 9 semanas de edad, y hacia la semana 12 ya está presente en el $80 \%$ de los túbulos evaluados(10). Este hallazgo coincide con la etapa de mayor aumento en el peso de los epidídimos, y con el mayor aumento de la altura del epitelio en la cabeza y el cuerpo, observado en el presente estudio, lo cual concuerda con hallazgos anteriores en $\operatorname{ovinos}(8)$ y $\operatorname{caprinos}(23)$.

La cola del epidídimo comenzó a desarrollarse antes del acelerado crecimiento de los testículos(10). En ese momento todavía no existe una contribución del fluido tubular a través del sistema de conductos, debido a que la luz de los túbulos seminíferos no se ha formado todavía(10). Tales hallazgos sugieren que el desarrollo inicial de la cola del epidídimo podría no depender de la presencia de testosterona u otros factores procedentes del sistema tubular testicular. Evidencias adicionales que apoyan esta posibilidad se han presentado en estudios con machos cabríos adultos, cuyos conductos eferentes fueron ligados(23); en estos animales fue evidente la falta de dependencia morfológica y funcional de la cola del epidídimo hacia las secreciones procedentes de los testículos, a través del sistema de conductos extra testiculares(23). Cuando la cola del epidídimo comenzó a desarrollarse, la concentración plasmática de testosterona debió haber sido muy baja(10,13); por lo tanto, el desarrollo inicial de la cola puede no depender de concentraciones altas de testosterona, o bien, depender de otros esteroides predominantes diferentes a la testosterona, como la androstenediona, cuyas concentraciones circulantes son mayores a esa edad(24,25,26). También existe la posibilidad de que el umbral de respuesta de la cola del epidídimo a la testosterona y a otros andrógenos circulantes sea menor a esa edad.

\section{CONCLUSIONES E IMPLICACIONES}

En conclusión, los datos del presente estudio indican que el desarrollo del epidídimo en ovinos

\section{CONCLUSIONS AND IMPLICATIONS}

In conclusion, data of the present study indicate that the pattern of development of the epididymis in sheep is regionalized, going from cauda to caput, that is, the cauda started developing earlier than the other anatomical regions. The development of cauda epididymidis should have started before the increase of testosterone concentration in blood plasma, and before the seminiferous tubule lumen appeared; in contrast, the caput and corpus development should have coincided temporally with the increase of the testicular steroidogenic capacity and tubular fluid secretion. Such findings suggest that the various anatomical regions of the epididymis have differential requirements of endocrine and lumicrine stimulation for their normal development.

\section{ACKNOWLEDGEMENTS}

To the "Consejo Nacional de Ciencia y Tecnología", México, for financing the project (39290-B); Víctor Robledo and Adolfo Paulín, from the "Universidad Autónoma de Querétaro" (UAQ), for providing with, and caring for the lambs; Jesús Herrera for helping in tissue collection; Miguel Silva and Mary Guerrero (UAQ) for tissue processing. AD Vargas-Velázquez is a former student, under the supervision of the last author (HJS).

\section{End of english version}

es regionalizado, en dirección de la cola a la cabeza, es decir, la cola comenzó a desarrollarse antes que las otras regiones anatómicas. Es probable que el desarrollo de la cola del epidídimo debió haber comenzado antes del aumento de las concentraciones de testosterona en el plasma sanguíneo, y antes de la aparición de la luz de los túbulos seminíferos; en contraste, el desarrollo de la cabeza y el cuerpo 
debió coincidir en tiempo, con el aumento de la capacidad esteroidogénica de los testículos y con la secreción de los fluidos tubulares. Estos hallazgos sugieren que las diversas regiones anatómicas del epidídimo tienen diferentes requisitos de estimulación endocrina y lumicrina para su desarrollo normal.

\section{AGRADECIMIENTOS}

Se agradece al Consejo Nacional de Ciencia y Tecnología, México, por el financiamiento recibido (proyecto 39290-B); a Víctor Robledo y Adolfo Paulín, de la Universidad Autónoma de Querétaro (UAQ), por proporcionar y cuidar a los corderos; a Jesús Herrera por su ayuda en la obtención de los tejidos; a Miguel Silva y María Guerrero (UAQ) por el procesamiento de los tejidos.

\section{LITERATURA CITADA}

1. Segura JC, Sarmiento L, Rojas O. Productivity of Pelibuey and Blackbelly ewes in Mexico under extensive management. Small Rum Res 1996;21:57-62.

2. Wildeus S. Hair sheep genetic resources and their contribution to diversified small ruminant production in the United States. J Anim Sci 1997;75:630-640.

3. Turner $\Pi$. On the epididymis and its role in the development of the fertile ejaculate. J Androl 1995;16:292-298.

4. Cornwall GA. New insights into epididymal biology and function. Hum Reprod Update 2009;15:213-227.

5. Gatti JL, Castella S, Dacheux F, Ecroyd H, Metayer S, Thimon $V$, et al. Post-testicular sperm environment and fertility. Anim Reprod Sci 2004;82:321-339.

6. Amann RP. Function of the epididymis in bulls and rams. J Reprod Fertil Suppl 1987;(Suppl 34):115-131.

7. Turner TT, Bomgardner D, Jacobs JP, Nguyen QA. Association of segmentation of the epididymal interstitium with segmented tubule function in rats and mice. J Reprod Fertil 2003;125:871-878.

8. Nilnophakoon N. Histological studies on the regional postnatal differentiation of the epididymis in the ram. Anat Histol Embryol 1978;7:253-272.

9. Bielli A, Genovese $P$, Ungerfeld $R$, Katz $H$. Histology of lamb epididymal development. Anat Histol Embryol 2007;36:437141.

10. Herrera-Alarcón J, Villagómez-Amezcua E, González-Padilla $\mathrm{E}$, Jiménez-Severiano $\mathrm{H}$. Stereological study of postnatal testicular development in Blackbelly sheep. Theriogenology 2007;68:582-591.

11. Jiménez-Severiano $\mathrm{H}$, Reynoso ML, Roman-Ponce SI, Robledo VM. Evaluation of mathematical models to describe testicular growth in Blackbelly ram lambs. Theriogenology 2010;74:1107-1114.

12. Monet KC, Hochereau-de Reviers MT, Terqui M. Variations in testicular androgen receptors and histology of the lamb testis from birth to puberty. J Reprod Fertil 1984;70:203210.

13. Montiel-Olguín LJ. Desarrollo endocrino del eje reproductivo en ovinos de pelo [tesis maestría]. Cuautitlán Izcalli, Estado de México: Universidad Nacional Autónoma de México; 2010.

14. Zhu LJ, Hardy MP, Inigo IV, Huhtaniemi I, Bardin CW, MooYoung AJ. Effects of androgen on androgen receptor expression in rat testicular and epididymal cells: a quantitative immunohistochemical study. Biol Reprod 2000;63:368-376.

15. Robaire B, Hamzeh M. Androgen action in the epididymis. J Androl 2011;32:592-599.

16. Robaire B, Hinton BT, Orgebin-Crist MC. The epididymis. In: Neill JD editor. Physiology of reproduction. $3^{\text {rd }}$ ed. San Diego, CA USA: Elsevier Academic Press; 2006:1071-1148.

17. Goyal HO, Williams CS, Khalil MK, Vig MM, Maloney MA. Postnatal differentiation of the ductus deferens, tail of the epididymis, and distal body of the epididymis in goats occurs independently of rete testis fluid. Anat Rec 1999;254:508520.

18. Hamzeh M, Robaire B. Effect of testosterone on epithelial cell proliferation in the regressed rat epididymis. J Androl 2009;30:200-212.

19. Wildeus S, Entwistle KW. A quantitative histological study of testicular and epididymal development in Bos indicus cross bulls. Anim Reprod Sci 1983;6:1-10.

20. Robaire B, Seenundun S, Hamzeh M, Lamour SA. Androgenic regulation of novel genes in the epididymis. Asian J Androl 2007; 9:545-553.

21. Tomsig JL, Turner TT. Growth factors and the epididymis. J Androl 2006;27:348-357.

22. Russell LD, Bartke A, Goh JC. Postnatal development of the Sertoli cell barrier, tubular lumen, and cytoskeleton of Sertoli and myoid cells in the rat, and their relationship to tubular fluid secretion and flow. Am J Anat 1989;184:179-189.

23. Goyal HO, Hutto V, Maloney MA. Effects of androgen deprivation in the goat epididymis. Cells Tissues Organs 1994;150:127-135.

24. Amann RP. Endocrine changes associated with onset of spermatogenesis in Holstein bulls. J Dairy Sci 1983;66:26062622.

25. O'Shaughnessy PJ, Baker PJ, Heikkilä M, Vainio S, McMahon AP. Localization of 17ß-hydroxysteroid dehydrogenase/17ketosteroid reductase isoform expression in the developing mouse testis-androstenedione is the major androgen secreted by fetal/neonatal Leydig cells. Endocrinology 2000;141:2631-2637.

26. Teerds KJ, Rijntjes E. Dynamics of Leydig cell regeneration after EDS. A model for postnatal Leydig cell development. In: Payne AH, Hardy MP editors. The Leydig cell in health and disease. 1st ed. Totowa, NJ, USA: Humana Press; 2007:91-116. 